one of detoxication. In the same paper he records that tocopherol administration to rats can prevent the hæmolytic action of alloxan, but not its necrogenic effect upon the pancreas.

Another interesting paper is that by W. G. Clark and T. A. Geissman on "The Role of Flavonoids and Related Substances in Biological Oxidations". The authors stress the important effects which may follow the capacity of substances of this class of chelating with metals such as iron, copper, cobalt and zinc.

Taken as a whole, the volume is stimulating, although it is now some considerable time since the conferences took place. One feels, perhaps, that the contributions might just as well have found their way into the recognized journals where they would have attracted the attention of both specialists and those more generally interested in these topics. As it is, the volume recording the conferences is likely to find its way into the bookshelves of the specialists only. They will no doubt be glad to have all the material conveniently assembled under a single cover.

\section{NUFFIELD FOUNDATION}

\section{ANNUAL REPORT FOR 1949-50}

$\mathrm{D}$ URING its first quinquennium the Nuffield Foundation selected and supported projects which seemed likely to advance the frontiers of knowledge in the medical, natural and social sciences, and particularly projects which seemed likely to contribute to the betterment of life. Many of the Foundation's earlier interests are being further pursued or rounded off as part of its present programme, and the Foundation announced in its fourth annual report its intention of seeking opportunities of furthering the search for new knowledge, especially in the fields of biological and sociological studies, and also of supporting or initiating attempts to apply existing knowledge to practical problems of contemporary importance. In its support of fundamental research, the Foundation has manifestly sought to assist work in fields which would often otherwise be neglected and thus to restore some balance in the advancing front of science.

Not content with its earlier efforts to break into new ground, to nurture some of the more immediate post-war requirements of teaching and research in the United Kingdom, and especially to enable academic studies to be re-started and re-staffed on a scale sufficient to attract the research workers who had been drawn away during the War, the Foundation is now significantly broadening the scope of its benefactions. It has always recognized the importance of the universities in Britain being able to offer the fullest opportunities to postgraduate students from the British Commonwealth, but its own grants have been confined to research in Great Britain. In its fifth annual report for the year ending March 31, 1950*, the Nuffield Foundation indicates that it is now considering the possibility of encouraging research in some of the Dominion universities and associated institutions. It is pointed out that the help which the Foundation will be able to offer for research overseas is bound to be highly selective and limited in amount, and the first such grant for fundamental research overseas announced in this report is for $£ 25,000$ over ten years for the endowment of the

* Nuffield Foundation. Report for the Year ending 31 March, 1950. Pp. 86. (London: Nuffield Foundation, 1950.)
Nuffield research chair of mechanical engineering in the New South Wales University of Technology. The chair is intended to enable the Nuffield professor to concentrate on new developments in the theory and practice of mechanical engineering and on the solution, through the medium of mechanical engineering, of some of the problems obstructing the full economic development of Australia.

The Foundation recognizes the important role of the universities of the British Commonwealth and the university colleges of the Colonies in training professional and technical leaders and in guiding and guarding the characteristic way of life and thought of the societies which they serve and help to mould; but the Foundation emphasizes that such work should receive recognition and encouragement from Great Britain. The strengthening of academic links throughout the Commonwealth may affect the growth and spread of all those other activities in which Britain should be lending its great and much-desired influence. Nevertheless, the new departure will not mean any slackening in the support given to work in Great Britain.

Grants promised during this first year of the

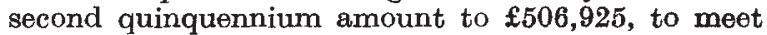

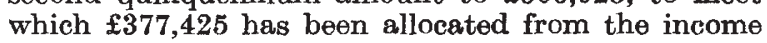
of the year, in addition to previous grants totalling $£ 135,000$. Of this, $£ 38,725$ is for research in rheumatism from the Oliver Bird Fund, with a promise of a further $£ 31,500$. For fundamental research, $£ 46,750$ has so far been given to biological and $£ 33,000$ to sociological studies, while $£ 225,300$ has been allocated from the income of the year towards fellowships, scholarships and similar awards, to be operated over the whole quinquennium, leaving $£ 173,000$ to be met from the remaining years; $\mathfrak{f 6 0 , 0 0 0}$ is to be paid as the remainder of the Foundation's promised share in supporting the National Corporation for the Care of Old People. Miscellaneous grants totalling $\$ 19,300$ include a further $£ 16,000$ to the Association of Universities of the British Commonwealth for travelling expenses in connexion with its annual meetings.

Grants in continuation of the past programme include, in the natural sciences, a new grant of $\mathfrak{\$ 3 2 , 0 0 0}$ over a further three years, in termination of the original grant, to the Biomolecular Research Laboratory at Birkberk College, London, where the studies envisaged include the investigation of the structure-types of the simpler compounds of biological importance, including those that might throw any light on protein and virus structure, and the systematic investigation of the low-molecular weight crystalline proteins and of crystalline viruses. The electronics department of the Laboratory is concentrating on the improvement of electronic and associated techniques and the investigation of the electronic properties of dielectries and semi-conductors, while the electronic-computing section is attempting to reduce the time required for the laborious computations needed for crystal structures and to make possible computing of protein and virus work which could not be carried out at all by existing methods. For additional work on the physiology of learning at the Department of Anatomy, University College, London, an extra grant of $£ 370$ a year for two years has been made and $£ 3,000$ has been allotted to the inquiry into the fundamental principles that should be applied in shaping agricultural policy for Great Britain. A further grant of $£ 2,000$ over three years has been made towards the pilot surveys being 
conducted for the Third Statistical Account of Scotland.

Grants from the Oliver Bird Fund, totalling $£ 48,800$, have been allocated for a programme of research on cortisone, the pituitary adreno-corticotrophic hormone and similar substances, as well as a further $£ 8,825$ for other researches into rheumatism. In this work the Foundation is maintaining the closest possible liaison with the Medical Research Council, and representatives of the pharmaceutical industry have been approached with a view to even wider collaboration, by pooling the results of commercial and academic research upon the problems presented by cortisone and adreno-corticotrophic hormone. This programme comprises a grant of $£ 1,000$ for apparatus and $£ 10.000$ over three years to the School of Biochemistry, Cambridge, for work on the isolation and purification of the pituitary adrenocorticotrophic hormone, its fission into peptides, and a study of their composition, structure and synthesis, as well as $\mathfrak{f 5 , 0 0 0}$ over three years to the University Chemical Laboratory for research on the synthesis of biologically active related peptides and on the synthesis of compounds with cortisone-like activity. $£ 10,000$ for three years has been granted to the Dyson Perrins Laboratory, Oxford, for a project for the partial or total synthesis of cortisone and analogous substances, and $£ 1,000$ for two years to the School of Chemistry, Royal Technical College, Glasgow, for an investigation of materials other than bile-acids as a source of cortisone-like substances.

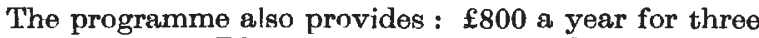
years to the Rheumatism Research Centre, Man. chester, for technical assistance in recording cliniophysiological data on the effect of cortisone and adreno-corticotrophic hormone; $\$ 5.000$ over three years to the Department of Biomolecular Structure, Leeds, for intensive examination of arthritic lesions supplied by the Rheumatism Research Centre; and $£ 10,000$ over five years to the research unit to be set up by the Department of Medicine, St. Mary's Hospital School, London, for study of the action of cortisone and adreno-corticotrophic hormone on various other disease states.

New grants for fundamental research in the biological sciences include $\mathfrak{\$ 8 . 2 5 0}$ over five years to the Department of Zoology, King's College, London, for the study of the differentiation between cell-types by nuclear and cytoplasmic transplantation, and by cytochemical methods; $£ 10,000$ to the Department of Anatomy, University College, London, for a fiveyear continuation of the research into the physiolngy of learning and the addition of an electronic engineer to the Department; $£ 15,000$ for five vears to the Laboratory of Chemical Crystallography, University of Oxford, for the formation of a research unit equipped with calculating machinery and computing assistance for the X-ray analysis of crystals of complex compounds; and $£ 12,000$ over five years to the trustees of the Strangeways Research Laboratory, Cambridge, for research on the structure and physiology of living cells, with special reference to the problems of cell division, and experimental investigation into the processes of cellular differentiation.

In the sociological field, the Foundation has provided $£ 6,000$ for an inquiry over three years by the Department of Economics, Aberdeen, into the budgets of young childless couples, married couples having their first child and married couples having their second baby, as well as $£ 12,000$ over three years for a systematic research, in collaboration with the
Tavistock Institute of Human Relations, on the development of various patterns of family life and the relative contribution of individuals and com. munity to these patterns. A grant of $£ 10,000$ has been promised to the London School of Economics and Political Science to meet for five years staff salaries for the new Division of Research Techniques. The principel concern of the Division will be research in the application of statistical techniques to social data and the study of sampling and interviewing techniques. A grant of $£ 5,000$ has also been made to the joint mental-survey committee of the Population Investigation Committee and the Scottish Council for Research in Education to follow the careers of the 12,000 sample children for the five-year stage until they reach eighteen years of age.

For the first stage of an investigation into the consistency of stop-watch time studies, to be conducted with a steering committee under the chairmanship of Sir Frederic Bartlett, the Foundation has set aside $£ 2,000$. The dental fellowships and scholarships and the Dominion travelling fellowships schemes are continued unaltered, but a new scheme of United Kingdom medical fellowships has been instituted, under which the emphasis is changed to future teachers and research workers. A new scheme of travelling fellowships for the Home Civil Service has been introduced, under which three fellowships a year are offered to Civil servants at the prineipal and assistant-secretary levels-and equivalents in the scientific grades-to visit other parts of the British Commonwealth for six months to a year. The first selection took place in March 1950.

Finally, there is foreshadowed in the report a scheme for extending the Nuffield Foundation Dominion travelling-fellowships-already in operation for Australia, Canada, South Africa and New Zealand-to the new Dominions of Ceylon, India and Pakistan. Since the report was published it has been announced that the following awards have been made : Ceylon, one fellowship (in medicine); India, five fellowships (two in medical sciences, and one each in engineering, natural sciences, and social sciences); Pakistan, three fellowships (subjects not yet selected). The object of the travelling-fellowships, which are open to men and women graduates, is to advance the interests of the new Dominions and to strengthen further their academic ties with the United Kingdom. The fellowships last for one year, and, according to whether the holder is married or single, are worth $£ 770-890$, in addition to travelling expenses (for a wife as well) to and from Great Britain.

\section{COTTON RESEARCH STATION, NAMULONGE, UGANDA}

$\mathrm{A}^{\mathrm{s}}$

S announced in Nature of November 18 (p. 850), the Parnell Laboratories at the Empire Cotton Growing Corporation's new Cotton Research Station at Namulonge, near Kampala, Uganda, were officially opened by H.E. Sir John Hathorn Hall, Governor of Uganda, on November 9. Among the large gathering of guests who witnessed the ceremony were H.H. the Kabaka of Buganda and the Nabagereka, Sir John and Lady Russell, Dr. and Mrs. B. A. Keen, Dr. H. H. Storey, and Mr. G. W. Nye, representing the Secretary of State for the Colonies. Mr. F. R. Parnell, the first director of the Station, and Mrs. Parnell 